\title{
Evaluation of Optical Characteristics by Panel Current Analysis for Charged Particle Type Display
}

\author{
박선우 ${ }^{1, a}$, 권기영 ${ }^{2}$, 장성 근 ${ }^{2}$, 김영조 $^{2}$ \\ (Sun Woo Park,
}

\begin{abstract}
The moving behavior of particle with voltage biasing is studied by analyzing the displacement current generated in electrodes and the drift current by moving particles in cell gap. These currents are ascertained by optical reflectivity on the panel. We obtained the saturated current after a peak in threshold voltage which is coincide with reflectivity of $80 \%$. These saturated optical reflectivity and its drift current offer optimum $\mathrm{q} / \mathrm{m}$ of particles and driving voltage and can be analytically studied on grey scale methods. Especially regional analysis is useful to aging and driving voltage and the understanding of operating mechanism of charged particle type display.
\end{abstract}

Key Words : Charged particle, Current, Charge controlled agent, Response time, Image force

\section{1. 서 론}

대전입자형 디스플레이는 마찰전기나 전계에 의 해 전하를 가지는 대전입자가 기판위에 많은 수의 셀(cell)이 Array되어 채워지며 각각의 셀 내부에 서로 반대되는 색과 전하를 가지는 대전입자가 인 가전압에 의해 상판에 유도되어 사용자가 이미지 를 인식할 수 있도록 하는 방식이다[1,2].

그림 1은 패널에 충전된 입자를 $\operatorname{SEM}($ Scanning electron microscope)을 통해 촬영한 사진이며 평 균지름은 약 $8 \mu \mathrm{m}$ 로 측정되었다. 사용된 입자의 구조는 폴리머(Polymer)를 기본으로 하며 구형으 로 이루어져 있으며 내부에 $\mathrm{CCA}$ (Charge Controlled Agent)가 존재하여 입자가 전하를 가지 도록 하였으며 대전입자의 외부에 도포된 나노사 이즈의 실리카(silica)가 입자의 유동성을 증가하도 록 하였다. 이 실리카로 인해 입자간의 응집현상을

1. 서울시립대학교 전자·전기·컴퓨터공학과 (서울시 동대문구 시립대길 13)

2. 청운대학교 전산·전자공학과

a. Corresponding Author : swpark@uos.ac.kr

접수일자 : 2009. 8. 28

1차 심사 : 2009. 9. 14

심사완료 : 2009. 9. 23
감소시킬 수 있으며 각각의 입자를 독립적으로 제 어할 수 있게 된다. 또한 $\mathrm{SEM}$ 이미지에서 관찰한 결과 이 입자들은 서로 같은 종류의 전하를 띠기 때문에 일정간격을 유지하여 마찰계수가 충분히 작아 유동성에 역시 영향을 미치고 있음을 알 수 있다[3-5]. 그림에서 실리카의 도포 상태를 흰색알 갱이로 확인된다.

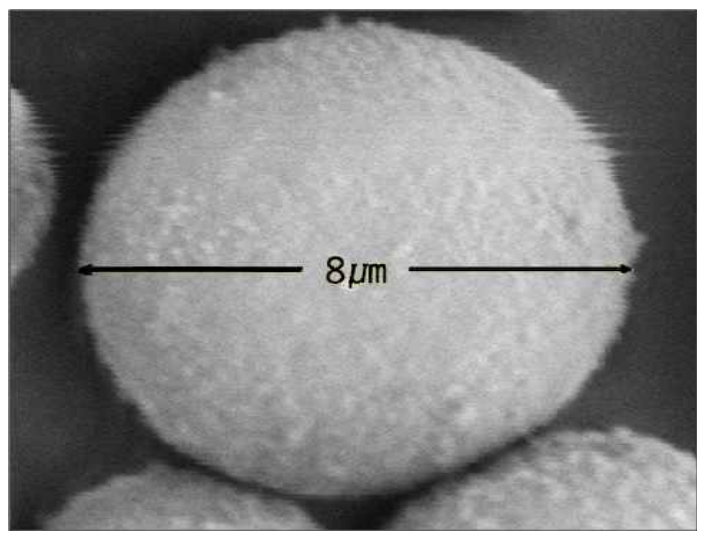

그림 1. 대전입자.

Fig. 1. Charged particles. 


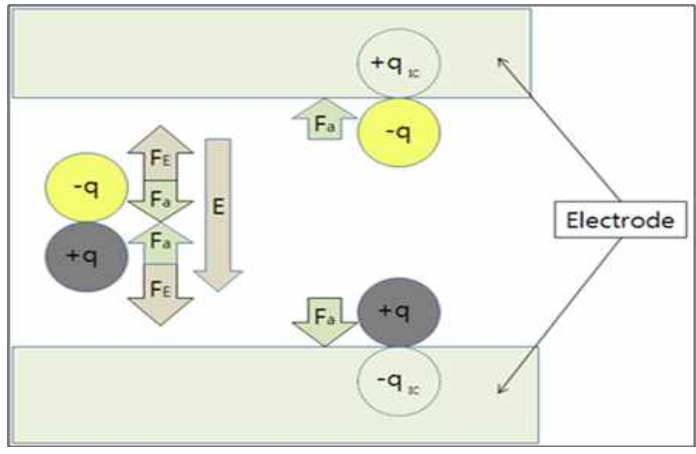

그림 2. 셀 내부에 작용하는 힘.

Fig. 2. Attractive force in a cell.

그림 2에서 보는 바와 같이 샐 내부에서 두 가 지 종류의 인력(Attractive force, $\mathrm{F}_{\mathrm{a}}$ )이 발생하는데 하나는 대전입자들 간에 발생하는 쿨롱 힘 (Coulomb's force, $F_{q}$ )이며 다른 하나는 전극이나 유전체의 분극으로 인해 대전입자와 전극이나 유 전체사이에 생성되는 힘(Image force, $F_{i}$ )이 존재 하게 된다. Image force로 인해 대전입자형 디스플 레이 소자는 최종이미지를 구현한 후에도 추가적 인 전력소비 없이 구현된 최종이미지를 오랜 시간 동안 유지시킬 수 있는 이른바 메모리 효과 (Memory effect)라 불리는 쌍안정특성을 가지게 된다. 또한 인가전압에 의해 생성된 전계로 인해 생성되는 힘이 존재하며 식 (1)과 같이 표현된다[6].

$$
F_{E}=q E=\frac{q V}{d}
$$

이 힘은 실질적으로 패널내 입자에 운동에너지 를 부여하는 힘이 되며 $\mathrm{d}$ 는 전극과 전극사이의 거 리(cell gap), $\mathrm{V}$ 는 인가전압, 그리고 $\mathrm{E}$ 는 셀갭에 작 용하는 전계이다. 셀 내부에 생성되는 운동에너지 에 작용하는 힘만을 고려하였을 경우 패널을 구동 하기 위한 조건은 식 (2)와 같다.

$$
F_{E}>F_{a}\left(F_{a}=F_{q}+F_{i}\right)
$$

이러한 조건을 만족하였을 경우 대전입자는 셀 내부를 운동하게 되며 전극에 접촉한 입자는 전극 과 입자 사이에 작용하는 힘 $\left(F_{i}\right)$ 로 인해 쌍안정성 에 의해 메모리 효과를 가지게 되어 일정한 이미 지를 전원 없이 유지하게 된다.

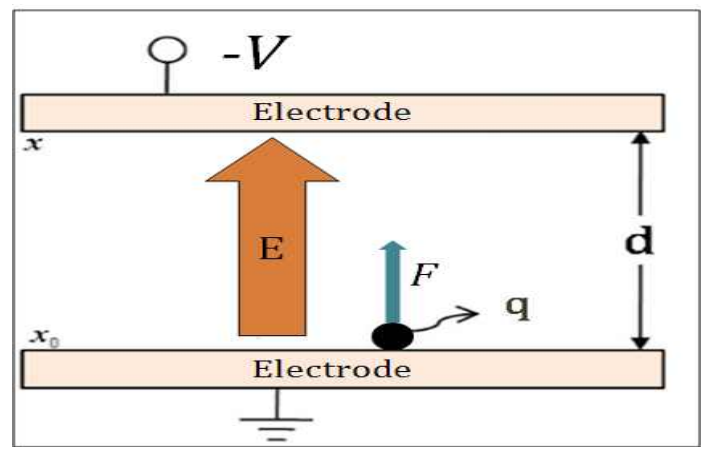

그림 3. 단일입자의 운동파라미터.

Fig. 3. Kinetic parameters of a particle.

그림 3 에서 보인바와 같이 인가전압에 의해 양 전하를 가지는 입자는 상판 쪽으로 이동하게 되며 운동하는 입자의 운동에너지와 전기에너지의 상관 관계를 정량화하면 입자운동에 필요한 전압은 다 음과 같이 표현된다[2].

$$
V_{m}=\frac{m v^{2}}{2 q}=\frac{m}{2 q}\left(\frac{d}{\tau}\right)^{2}
$$

이 식에서 $\mathrm{m}$ 은 입자의 질량, $\mathrm{q}$ 는 전하량, $\mathrm{v}$ 는 입 자의 속도, 그리고 $\tau$ 는 셀갭의 이동시간(응답시간) 이며, 이 식은 상판에 존재하는 양전하 하나를 반 대편 전극으로 이동하는데 필요한 전압을 알 수 있다. 따라서 앞서 언급한 문턱전압(Vth), 입자 간 에 응집현상에 기인하는 쿨롱힘 $(\mathrm{Vq})$, 그리고 입자 의 운동에 기여하는 전압 $(\mathrm{Vm})$ 을 고려하여 운동하 는 입자가 최초 발현되는 구동전압 $\left(V_{d}\right)$ 은 다음과 같이 표현된다.

$$
V_{d} \geq V_{m}+V_{t h}+V_{q}
$$

그림 4에서 보인 바와 같이 패널은 ITO전극이 증착되어 있는 상판과 하판이 서로 마주보고 있는 커패시터(Capacitor)로 간주될 수 있다. 셀내부에 입자가 존재하지 않을 경우는 전계에 의한 변위전 류성분 $\left(i_{d p}\right)$ 만이 측정될 것이나 상판과 하판사이에 양전하를 가지는 검은색 입자와 음전하를 가지는 노란색 입자가 주입되어 식 (4)를 만족하였을 경우 셀 내부에 생성된 전계에 의해 대전입자는 상판과 하판사이를 운동하게 되며 이때 운동하는 대전입 자로 인해 측정되는 전류성분은 변위전류성분과 


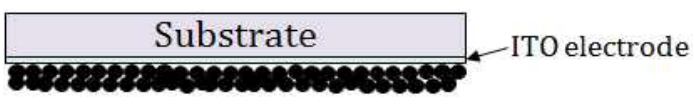

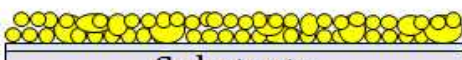 \\ Substrate}

그림 4. 전류측정을 위해 제작된 패널의 단면도.

Fig. 4. Crossectional view of a panel fabricated for current measurement.

표동전류성분의 합으로 측정된다. 즉 다음의 식이 성립한다.

$$
i_{\text {tol }}(t)=C_{\text {panel }} \frac{d v_{s}(t)}{d t}+n q A v_{d r i f t}
$$

본 연구에서는 대전입자형 디스플레이 소자 내 부에 존재하는 입자의 운동에 기인하는 전류성분 을 분석하여 구동전압, 입자의 운동성분과의 관계 를 이해하고, 계조표현에서도 전류분석이 타당함을 밝히고자 한다.

\section{2. 실 험}

\section{1 전류측정시스템}

그림 5 에서 보인 바와 같이 반사광 측정시스템 은 패널에 적절한 구동전압을 공급할 수 있는 펄 스발생기(Programmable pulse generator)와 패널 의 black bevel과 white level의 변화에 따른 반사 광을 수광할 수 있는 적분구(Integrating sphere)가 있으며 적분구 내부에 내장된 광원(Light source) 과 수광된 반사광을 전기신호로 변환시킬 수 있는 포토다이오드(Photo diode)로 이루어져 있다. 본 연구를 위한 반사율은 스펙트로미터, 시야각 및 반 사율을 동시에 실시간으로 측정할 수 있도록 설계 된 RT-200(2007년 J\&C사 모델)을 이용하여 측정 하였다.

또한 포토다이오드의 출력신호(Current)가 신호를 분석하는데 충분한 Dynamic range를 제공하지 않 으므로 증폭기(Amplifier)를 통해 분석 가능한 범 위로 신호를 증폭한 후 오실로스코프(Oscilloscope) 를 통해 출력신호를 디스플레이하는 구조로 되어 있다. 더불어 사용된 포토다이오드는 빛의 파장에

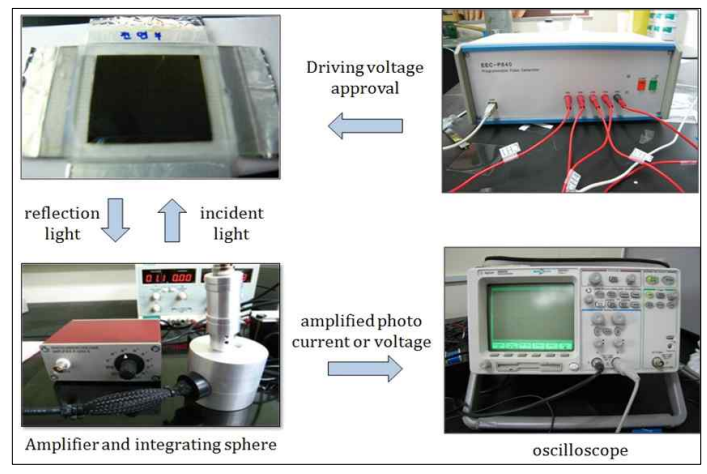

그림 5. 반사광 측정 시스템.

Fig. 5. Measurement system of reflected light.

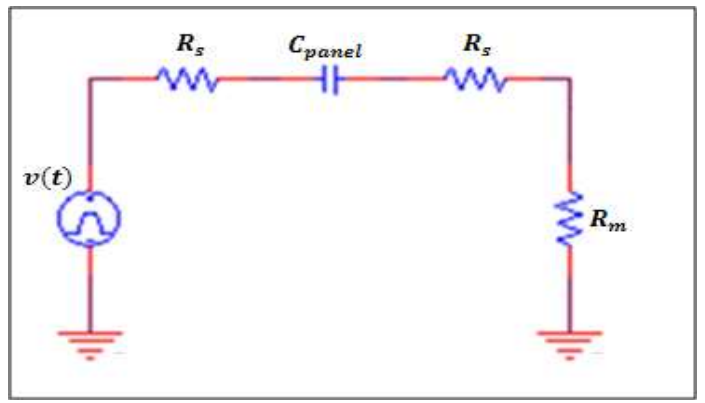

그림 6. 전류측정을 위해 구성된 등가회로.

Fig. 6. Equivalent circuit of current detection.

따라 감도가 다르지만 광이 Laser이며 그에 따른 상대적인 차이를 보고자 하므로 Radiometry에 관 한 Brightness정도만이 측정되어도 무관하다.

\section{2 전류측정시스템}

그림 6 과 같이 회로를 구성하여 전류를 측정하 였다. 패널의 양단에 $R_{s}$ 는 ITO전극으로 인한 시트 저항(Sheet resistor)이며 저항 $\left(R_{m}\right)$ 은 회로에 생성 되는 전류가 마이크로 단위의 낮은 진폭을 가지기 때문에 원활한 측정을 위해 높은 저항 값을 가지 는 저항을 회로의 끝단에 구성하여 이 저항의 양 단에 전위차를 측정하기 위함이다.

\section{3. 결과 및 고찰}

3.1 패널의 전류측정

실험을 위한 회로를 보인 그림 6 에서 저항 


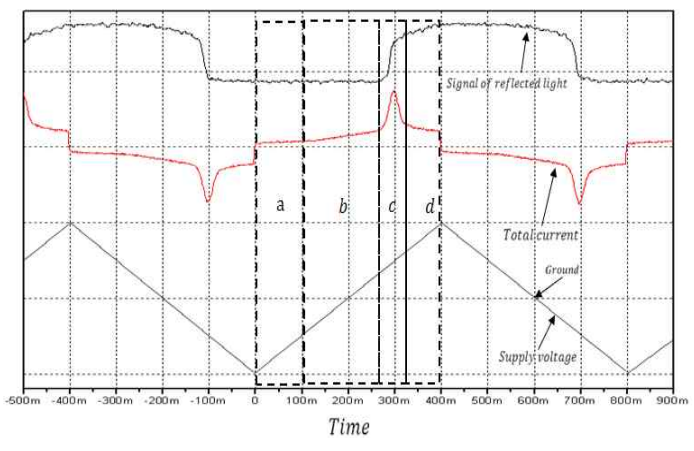

그림 7. 전류곡선과 반사광 곡선.

Fig. 7. Current curve and reflection curves.

$\left(R_{m}\right)$ 에 측정되는 전위차 $\left(v_{m e a}(t)\right)$ 는 식 (5)로부터 다음과 같이 표현된다.

$$
v_{\text {mea }}(t)=R_{m}\left(C_{\text {panel }} \frac{d v_{s}(t)}{d t}+n q A v_{\text {drift }}\right)
$$

먼저 그림 7의 전류 및 반사광 그리고 인가전압 에 대한 신호의 함수값은 상대적인 값만을 비교하 므로 제외되었음을 미리 밝혀두고자 한다. 삼각파 를 가지는 전압을 패널에 인가하였을 경우 시간에 대해 선형적으로 증가하는 인가전압으로 인해 패 널에 생성되는 미세전류와 반사광 특성을 검토할 수 있었다. 출력된 전류곡선을 보면 일정한 주기를 보이고 있음을 알 수 있다.

특히, 반주기만을 고려하여도 나머지 반주기가 역전된 진폭을 제외하고 커브는 동일하므로 전압 의 기울기가 양수인 부분만을 검토하여 대전입자 의 운동특성을 확인하고자 한다.

각각의 구간별로 대전입자의 운동특성은 다른 특성을 보이는데 그림 8에서 보인 바와 같이 $\mathrm{a}$ 구 간에서는 상판에 양전하가 대전된 Black입자와 하 판에 음전하가 대전된 Yellow입자가 Attractive force로 인해 안정적으로 유지되고 있다. 따라서 측정되는 전류는 변위전류성분만이 측정되었다. 더불어 상판의 검은색 입자로 인해 반사광의 출력 은 최저값을 가지게 된다. $\mathrm{b}$ 구간에서는 입자를 전 극에 고정시킬 수 있는 힘인 Attractive force가 전 계의 세기보다 작은 입자들이 반대편 전극방향으 로 이동할 수 있게 된다. 따라서 Attractive force 에 의한 메모리 효과로 안정적으로 상판에 유지하 고 있던 입자들이 점차 하판으로 이동하게 된다. 전계의 세기가 선형적으로 변하므로 하판 쪽으로

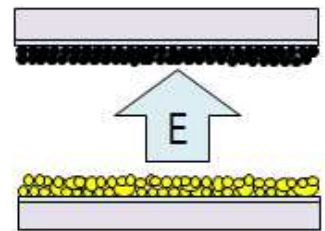

(a)

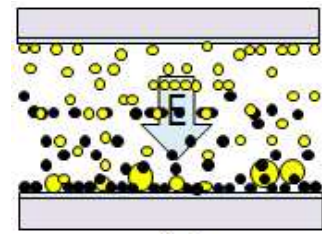

(c)

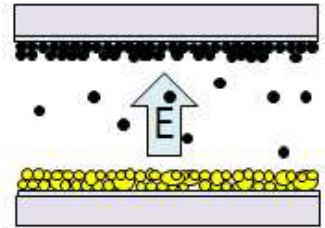

(b)

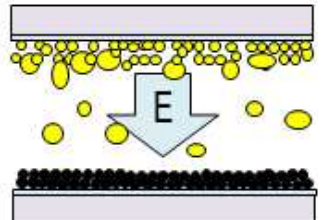

(d)
그림 8. 구간별 운동특성.

Fig. 8. Kinetic characteristics in each region.

이동하는 검은색 입자의 량 또한 선형적으로 증가 하여 Drift current에 일부 기여하게 된다. 그림 8 의 (b)에서 보인 바와 같이 전계의 세기변화에 가 장 많은 영향을 받는 전극에서 가장 멀리 떨어져 있는 입자만이 하판 쪽을 향해 이동하기 때문에 실제 반사광의 변화는 없다.

c구간에서는 인가전압이 문턱전압을 넘어서며 이때 운동하는 입자는 급격하게 증가하며 반사광 또한 이와 유사한 커브를 그리며 증가한다.

실제 셀 안에 주입된 입자의 양은 정해져 있으 며 입자의 지름이 불균일하므로 입자의 지름에 대 한 분포에서 평균값에 해당하는 입자들은 전압에 대한 조건이 만족된다면 그 순간에 가장 많은 Drift current가 생성될 것이다. 따라서 인가된 전 압에 대하여 상판으로 운동하는 입자는 급격하게 증가한다. 그림 8에 보인 시간에 대한 그래프는 실 제 인가전압이 일차함수이므로 시간 축을 전압 축 으로 변환하였을 경우에도 같은 형태의 커브가 그 려질 것이며 전류-전압곡선으로 해석하여도 타당 하다.

패널구동을 고찰하였을 경우 구동전압은 비전하 $(q / m)$ 가 다르기 때문에 어느 정도의 불균일성을 가진다. 그림 8에서 보는 바와 같이 실제 인가전압 대하여 운동할 수 있는 입자의 분포는 이 구간에 밀집되어 있으며 인가전압 대비 반사광효율이 약 $80 \%$ 에 육박하므로 이 구간에서 구동전압의 영역 을 정의하는 것이 적절하다고 판단된다. $\mathrm{d}$ 구간에서 는 구동전압 영역이상의 전압이 인가되고 있으며 반사광은 서서히 증가되고 있다. 이는 최적화된 


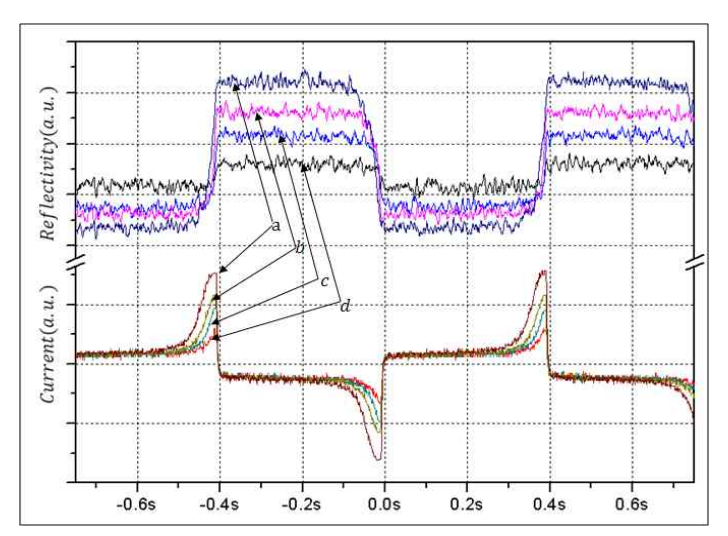

그림 9. 삼각파전압에 의한 계조.

Fig. 9. Grey scale by triangle waveform.

입자의 $\mathrm{q} / \mathrm{m}$ 을 가지는 입자들이 구동전압 영역에서 전부 이동하였음에도 불구하고 입자의 형태가 구 형이므로 입자사이에 공간이 존재하여 이 공간으 로 주변의 입자들이 이동하거나 높은 구동전압을 가지는 입자가 상판으로 이동하여 패널의 반사율 상승에 기여하게 된다. 그러나 전압대비 반사광의 효율을 고려하였을 경우 구동전압 이상이 인가되 고 있는 $\mathrm{d}$ 구간은 실제 패널을 제작하였을 경우 불 필요한 전압이 인가되고 있는 구간이다. 본 연구에 서 살펴본 전류해석은 향후 인가전압 및 에이징 전압을 결정하는데 유익할 것으로 생각되며, 또한 대전입자형 디스플레이의 동작메카니즘을 파악할 수 있는 중요한 요인이 될 것으로 생각된다[7].

\section{2 패널의 계조표현}

대개의 경우 계조표현방법으로 전압의 크기, 벌 스폭, 펄스의 상승시간에 의해 계조표현을 하는데 [8] 본 연구에서는 이러한 계조표현에 대한 분석을 전류성분으로 설명이 가능함을 보이고자 한다. 그 림 9에서 보인바와 같이 앞서 정의된 구동전압의 영역을 바탕으로 실제 패널에 최대전압과 최소전 압의 차이를 주어 4-level의 계조표현을 구현하였다.

그림 10 에서 보인바와 같이 구동전압영역내의 전압을 최대전압으로 설정한 후 인가전압을 구형 파로 형태로 인가하여 펄스폭에 변화에 따른 반사 광의 변화를 확인하였다. $0.4 \mathrm{~ms}$ 이하의 펄스폭을 가지는 구동펄스를 인가하였을 경우 패널의 반사 광의 변화는 발생하지 않았으며 이 상태에서 패널 의 Black level을 가지고 있게 된다. $0.6 \mathrm{~ms} \sim 1.2 \mathrm{~ms}$ 의 각각의 구동펄스를 인가하였을 경우 반사광이

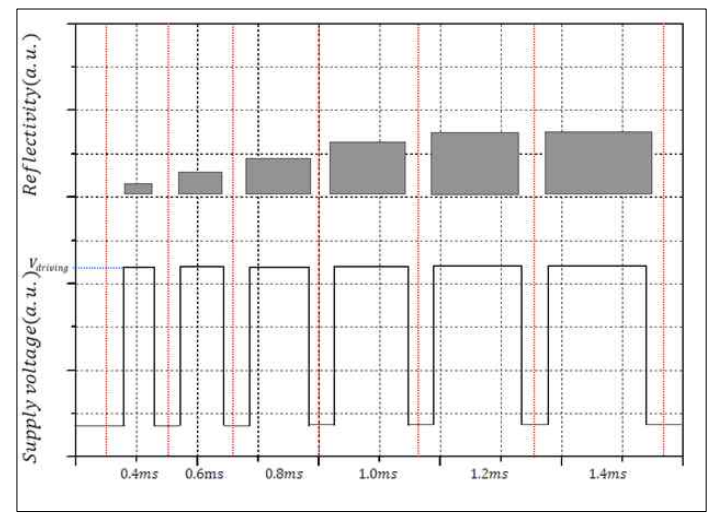

그림 10. 펄스폭 의한 계조표현.

Fig. 10. Grey scale by pulse width modulation.

선형적으로 증가하는 것을 확인하였으며 $1.4 \mathrm{~ms}$ 의 구동펄스를 인가하였을 경우 반사광이 더 이상 증 가하지 않는 것을 확인하였다. 이러한 특성이 가능 한 이유는 입자의 운동을 유도할 수 있는 충분한 힘이 주어졌음에도 불구하고 인가전압에 대한 운 동량의 차이로 인한 것이다. 실제 주입된 입자의 $\mathrm{q} / \mathrm{m}$ 이 다르기 때문이며 입자가 패널 내부를 운동 할 수 있는 운동량에 대한 충분한 시간이 공급되 어야 함에도 불구하고 펄스폭이 조건을 만족하지 못하기 때문에 이로 인해 운동할 수 있는 입자의 양이 차이를 보이게 된 것으로 판단된다. $1.4 \mathrm{~ms}$ 의 펄스폭을 가지는 구동펄스가 인가되고 있음에도 불구하고 반사광의 변화가 나타나지 않는 이유는 설정된 전압 $\left(V_{\text {driving }}\right)$ 으로 인해 운동할 수 있는 입 자의 양은 이미 포화되었으며 펄스폭을 더 이상 증가하여도 추가로 운동할 수 있는 입자는 존재하 지 않게 된다. 이 실험 반사율의 포화를 고려하면 전류분석으로 설명될 수 있음은 자명하다고 판단 된다.

\section{4. 결 론}

패널에 삼각파 전압을 인가하여 이때 패널이 이 루고 있는 커패시터 형태로 인해 생성되는 변위전 류와 상판과 하판을 이동하는 입자로 인해 생성되 는 표동전류를 측정하여 인가전압에 따른 입자의 거동을 확인하였으며 측정된 반사광(약 $80 \%)$ 과 구 동전압의 효율을 검토하여 대전 입자형 디스플레 이 패널구동에 관한 최적화 방법을 제시하였다. 인 
가전압에 따라 운동하는 입자량의 변화를 구간으 로 나누어 전류와 연관하여 확인하였으며 일반적 으로 적용되고 있는 계조표현방법도 본연구의 전 류분석으로 규명될 수 있음을 보였다. 본 연구에서 살펴본 전류해석은 향후 인가전압 및 에이징 전압 을 결정하는데 유익할 것으로 생각되며, 또한 대전 입자형 디스플레이의 동작메카니즘을 파악할 수 있는 중요한 요인이 될 것으로 생각된다.

\section{감사의 글}

이 논문은 서울시립대학교 안식년 연구지원 자 금으로 수행되었습니다. 또한 본 논문은 2009년 소 재원천 기술개발사업(과제번호 M20070100131)지원 으로 수행되었습니다. 이에 감사드립니다.

\section{참고 문헌}

[1] R. Hattrori, S. Yamada, Y. Masuda, N. Nihei, and R. Sakurai, "Ultra Thin and Flexible Paper-Like Display using QR-LPD Technology", SID DIGEST 04, p. 136, 2004.

[2] T. Kitamura, "Electronic Paper Based on particle Movement Electrophoretic and Toner Display", IDW 06, p. 587, 2006.
[3] D. J. Lee and Y. C. Kim, "Response characteristics of charged particle type display", J. of KIEEME(in Korean), Vol. 22, No. 2, p. 169, 2009.

[4] D. J. Lee, S. W. Kim, C.- J. Kim, and Y.-C. Kim, "Fabrication and driving of charged particle type display", Proc. 2007 Summer Conf. KIEEME, Vol. 8, p. 72, 2007.

[5] D. J. Lee, I.-H. Kim, and Y.-C. Kim, "Studies on parameters and voltage characteristics of cell for charged particle type display", Proc. 2008 Summer Conf. KIEEME, Vol. 9, p. 89, 2008.

[6] R. Hattrori, S. Yamada, Y. Masuda, and N. Nihei, "A novel bistable reflective display using quick-response liquid powder", Journal of the SID 12/1, p. 136, 2004.

[7] I. H. Kim and Y. C. Kim, "A study on response time characteristics of toner particle type display", J. of KIEEME(in Korean), Vol. 22, No. 1, p. 93, 2009.

[8] S. H. Kwon, S. G. Lee, W. K. Cho, B. G. Ryu, and M.-B. Song, "Reflective Paper-like Display using Opposite--charged Two Particles", IMID DIGEST 05, p. 423, 2005. 